\title{
OS GIGANTES DA ALMA DO CIRURGIÃO
}

\section{THE GIANTS OF THE SURGEON'S SOUL}

\section{Fernando Pitrez-TCBC-RS}

O mestre e cientista da alma, Emilio Mira Y López, nos idos de 1947, sabiamente abordou a intimidade anímica da natureza humana em consagrada obra intitulada Cuatro Gigantes del Alma: el Miedo, la Ira, el Amor, el Deber. As grandes reações neuro-psíquicas, o Medo, a Ira, o Amor agregadas à força repressiva originada pelas exigências da vida em sociedade - o Dever - foram por ele rotuladas como os Quatro Gigantes da Alma. Os três primeiros foram considerados como "gigantes naturais" ao passo que o último constituirse-ia no "gigante social" que, de certo modo, deriva deles e contém algo de cada um em sua distinta contextura.

Em cirurgia, da mesma forma, classicamente, são descritos Os Quatro Gigantes da Alma do Cirurgião, respectivamente: a Complicação, $\boldsymbol{a}$ Seqüela, a Recidiva e o Óbito que retratam de modo um tanto poético o drama vivido por cirurgiões quando um destes eventos agrava e tumultua o pósoperatório. Embora todos sejam preocupantes, sem dúvida alguma, o último é o mais temido, pois revela o fracasso total e definitivo da intervenção em prol da vida.

Alicerçado em um raciocínio similar ao empregado por Mira y López, aos quatro descritos, ousaria agregar um quinto gigante, mais atual, decorrente dos demais e atemorizante para o médico em geral e, em particular, ao cirurgião. Refiro-me ao Processo judicial por alegado erro médico - uma legítima espada de Dámocles a pairar ameaçadora sobre a lide do cirurgião - que se afigura cada vez mais trivial e tão a gosto da sociedade. Inclusive é utilizado, não raramente, por pacientes e causídicos mal intencionados, como pretexto para encobrir a verdadeira finalidade, qual seja a de obter reles vantagens pecuniárias. $\mathrm{O}$ permanente temor por parte dos componentes de nossa classe, frente a essa possibilidade sempre presente, obscurece a mente e influi negativamente no raciocínio clínico, diante de decisões mais delicadas. Ao contrário dos antecedentes, que são de fundo eminentemente cirúrgico, origina-se do judiciário e de pouca lida e conhecimento por parte do universo cirúrgico.

Em sentido mais amplo, conceitua-se o erro médico como sendo "a falha no exercício da profissão.” É sabido que a responsabilidade cível e criminal por atos médicos, de execução ou inércia, poderá resultar em três modalidades de culpa: imprudência, negligência e imperícia. A caracterização da simultaneidade das três em um único ato, irá decretar o que é tido como erro médico.

A simples menção desses três vocábulos, no momento, causa preocupação e tenção ao meio cirúrgico, de tal maneira, que passam a incorporar o vocabulário médico, não havendo sequer um único cirurgião que desconheça o seu significado e as implicações decorrentes.

O temor ao erro médico, é parte integrante da prática cirúrgica hodierna, quase tanto quanto as apreensões inerentes ao ato operatório. Constitui-se, pois, em um gerador acessório que vem somar-se aos naturais sobressaltos, motivados pelo desenrolar de um pós-operatório tumultuado, por fortuitas ocorrências indesejáveis, passíveis de imputabilidade legal. Uma vez ou outra, esta inevitabilidade, ao ser questionada judicialmente, é de difícil convencimento ao julgador. Ao médico, não é lícito a falibilidade própria ao ser humano. A ele é cobrada a onipotência da deidade, sendo-lhe imposta uma injusta e sorrelfa cobrança por parte da hedonista sociedade atual. A respeito caberia evocar a reflexiva sentença de Franklin Roosevelt: "O único homem que não comete erros é o que nunca fez nada".

Atualmente, os feitos médicos dignificantes ocupam a imprensa, muito menos do que a divulgação do erro presumível. A mídia, sensacionalista e ávida por manchetes e notícias escandalosas, atende ao anseio da população, divulgando possíveis equívocos de forma sensacionalista, denegrindo tendenciosamente a figura do médico.

Com isso não estamos a justificar genericamente os autênticos erros médicos. A bem 
da legitimidade, entendemos que todos os atos de natureza médica contestados em juízo, devam ser exaustivamente investigados em todas as esferas.Na hipótese de uma comprovada culpabilidade, que sejam usados os instrumentos legais cabíveis para a respectiva sansão; se inocentada, que seja devidamente espiada.

Inicialmente, de incumbência dos Conselhos Regionais, a decisão sobre a culpabilidade ou não, do réu cirurgião foi legada ao âmbito do Poder Judiciário que se apossou da prerrogativa do julgamento, onde o médico vê-se julgado, cível e criminalmente. Aos Conselhos restou a fiscalização da conduta ética e a punição administrativa que se estende desde a mera advertência verbal à proibição formal do exercício médico, com a cassação do registro profissional. Atribuiu-se à ação contra o corporativismo nefasto, a transposição deste fórum de juízo, com o que não concordo.

Como antídoto, várias opções têm sido apregoadas por entendidos no assunto. Entre elas, pode-se ressaltar, de início, duas medidas práticas. A primeira refere-se ao Prontuário que deve ser completo e explícito em todos os itens, nos mínimos detalhes pois é do seu conteudo que são recolhidas as provas, tanto de acusação como de defesa. O que não consta nos autos (no caso, o prontuário) não é considerado como prova. Infelizmente, na maioria dos casos, o preenchimento deste tópico é negligenciado, seja por desídia ou comodidade, por parte dos médicos,acarretando, com isso, sérios prejuízos às alegações de sua defesa.

A outra providência, de caráter é parte integrante do prontuário médico, sendo raramente desdenhada. Neste aspecto, até mesmo, a problemática da compreensão acerca da doença pelo paciente já é tratada no próprio Código de Ética Médica no capítulo "Relação com o paciente e Familiares" a quem cabe, em última análise, a decisão final ao que deverá ser submetido, obviamente tratando-se de uma situação cirúrgica eletiva.

Todavia, é prudente analisar esse último tema, com prudência, uma vez que a sua efetivação pode macular a delicada relação médico/paciente,o que não é desejável, sob nenhuma hipótese. Esta, em meu entendimento, constitui-se provavelmente no fator protetor primordial, na prevenção de um eventual processo.

Seja como for, o temor ao suposto erro médico - o quinto perverso gigante da alma do cirurgião - veio juntar-se definitivamente ao dia a dia do cirurgião moderno. Talvez se possa afirmar que o mesmo seja atualmente, muito mais assustador do que as decorrências próprias da cirurgia, restritas unicamente à esfera médica. O receio devido à pena pecuniária é o grande problema que atualmente alvoroça e aflige a classe de cirurgiões. 